\title{
The Political undertone in the development of nomadic education in Africa: Lessons from Nigeria
}

\author{
Louis Akpan \\ National Open University of Nigeria, Lagos, Nigeria
}

\begin{abstract}
This study examines the dynamics that necessitated the conceptualisation and development of nomadic education programme by the military government of Nigeria in 1986. Because of the nature of the paper which has some political connotations, governmentality theory by Foucault was adopted. In this paper, however, two methods of data gathering (oral interview and archival materials) were used. From the findings, it was discovered that the 1979 Nigerian Constitution, various International Conventions and Treaties, National Policy on Education and Miyetti Allah Cattle Breeders Association significantly influenced the conceptualisation of nomadic education programme in Nigeria. Furthermore, it was also revealed that the implementation of newly introduced nomadic education in Nigeria was made possible by the promulgations of some decrees.
\end{abstract}

KEYWORDS: Nomads, nomadic education, military government of Nigeria, governmentality, decrees.

\section{Introduction}

Governments the world over place emphasis on education as a vehicle through which the country's economic, political, social, and technological advancement can be achieved. Nigeria is a developing country and has attempted to uplift education to an acceptable level through the provision of basic and functional education to her citizens and has declared the first 9 years of Basic Education free and compulsory (Musa \& Isa, 2018). Despite the government's intent in providing quality and functional education at all levels to Nigerians irrespective of age, religion, tribe or gender to fulfil the goals of Education for All (EFA) movement, her effort in this regard appears to be unachievable (Tahir, 2000). This assumption is premised on the fact that, there still exists a particular group of Nigerians, who hitherto are being side-lined from this goal of having access to basic and functional education, due to their geographical location and occupational practices. This particular group of Nigerians are the nomads.

In this study, nomads are group of people that migrate orderly, logically, systematically and purposefully from one particular geographical region to the other in search of their means of livelihood. According to National Commission for Nomadic Education (NCNE) (2010), there are three major categories of nomads in Nigeria. These include: the nomadic pastoralists, artisanal migrant fishermen and migrant farmers (NCNE, 2010). The nomadic pastoralists are made up of the Fulbe (5.3 million), the Shuwa (1.0 million) the Koyan (32.000) the Badawi 
(20.000) the Buduma (10.000) and the Dark Buzzu (15.000) (Tahir, 2003). Ahmed (1997) opines that the Fulbe are found in 31 out of the 36 states in Nigeria, while other pastoralists are mainly found in the Borno plain and on the shores of Lake Chad (Osokoya, 2010). From a pilot study I conducted in 2014, it was revealed that out of the estimated population of 26.8 million nomads in Nigeria more than 15.3 million are children of school-going age who have limited access to formal education. The limited accessibility of nomadic children to formal education was a source of concern to the government of Nigeria, hence the introduced nomadic education in 1986.

From the formative phase of nomadic education programme in 1986 to-date, different nomadic education policies have been formulated and enacted by the federal government for the implementation of nomadic education in Nigeria. It is now almost 33 years since the formal launch and commencement of the nomadic education programme in Nigeria. In light of the above, there is a need to critically examine the history of nomadic education policies. Against this background, therefore, the paper is out to examine the rationale for the conceptualisation of nomadic education by the then federal military government of Nigeria in 1986. Secondly, it also examined the decree promulgated by the military administration for evolution of nomadic education in Nigeria. The signposting is necessary in order to shed light on the context in which the study was undertaken and also to provide the basis for conducting on the history of nomadic education policies in Nigeria.

\section{Brief historical overview of Nigeria}

The geographical expression known today as Nigeria was a creation of the British colonial adventurers and empire builders. The British conquered different parts of what is today known as Nigeria at different times during the 19th century. In 1905, the British government established her presence over all of present day Nigeria. One paramount aspect of early colonial rule is that the territory of Nigeria was actually two colonies which were known as the Southern and Northern Protectorates respectively. In 1914, the two protectorates were amalgamated by Governor-General Sir Lord Lugard. Lady Lugard (wife of the Governor-General of Nigeria) named these amalgamated protectorates Nigeria in 1914. This name was derived from the river Niger that constitutes a remarkable geographical feature in Nigeria. In 1939, Southern Nigeria was divided into two parts - Eastern and Western Nigeria. Still under colonial rule in 1954, the country was further divided into three main parts namely: East, West and Northern Nigeria. Post-independence, in 1967, the country was further divided into 12 states by the then Head of State, General Yakubu Gowon. The creation of 12 states was driven by the need to weaken the secession threat of the then Eastern region led by Lt.Col. Odimegwu Ojukwu. In 1976, seven additional states were created to make up 19 states. From 19 states, it was further extended to 23 states in 1987 and 30 states in 1991. At present, Nigeria has 36 states with political and administrative headquarter situated in Abuja. The creation of more states in Nigeria by each military administration that ruled the country between 1966 and 1999 was to satisfy some sections of the Nigerian society who cried of marginalisation by the federal government.

Politically, it is worthy to mention that the colonised Nigeria before independence was perceived by Nigerians as an illegitimate foreign system, operated according to unfamiliar rules and norms which could not functions to promote a sense of common natural identity among the diverse ethnic groups or even the three regions that made up the country then (Abbas \& Yigit, 2016; Ahmed, 2016; Constantine, 2017; Kaya, 2016; Bassey, 1999). Nigeria finally got her independence on $1^{\text {st }}$ October, 1960, under a conservative federal coalition government which had Dr Nnamdi Azikiwe as Governor General, Tafewa Balewa as Prime Minister and Chief Obafemi Awolowo as the leader of opposition. Within two years of independence, the 
political agreements which produced the federal government broke down. However, what looked like an experiment in democracy was extinguished as a result of irreconcilable differences among political players which formed the federal coalition government. In spite of the obvious collapse of the government, it still dragged on for three more years before it was finally overthrown by the military in 1966. The country was under military regime from 1966 to 1979 . Within this period, there were several military coups and counter-coups. On October 1, 1979, Nigeria was once again retuned to civilian rule under President Shagari. The civilian government of Shagari lasted for only three years before it was violently overthrown by the military led by General Buhari in 1983. However, General Mohammedu Buhari was forced out of office from what was officially regarded as palace coup led by General Ibrahim Babangida. Military occupation of Nigeria political space was seen by Nigerians as self-serving. During this period, Nigerian leaders welded unnecessary social, political and economic powers to serve their narrow interests. This assertion is supported by Momoh (2010) who argues that Nigerian leaders' inordinate political ambitions is what plunged the country into official bribery and corruption, religious bigotry, militancy, kidnapping, armed robbery, assassination, advance fee fraud, inflation, injustice, unemployment, abject poverty and nepotism. In recent time, there has been social disability in Nigeria expressed frequently via ethno-religious and communal violence. For instance, the emergences of indigene verse settler's dichotomy in the country significantly promote a rift in the existing Nigerian federal framework. In addition, it is worthy to mention that the formation of ethnic militias such as Arewa People's Congress, Bakassi Boys, Odua People's Congress, Egbesu, Niger Delta Volunteer Force, Movement for the Actualisation of Sovereign State of Biafra (MOSSOP), Indigenous Peoples of Biafra (IPOB) were done by 'ethnic leaders' to promote a sub-national agenda since the federal government of Nigeria has failed to cultivate unity and oneness in the mind of her citizens.

In Nigeria, corruption has become a way of life. Corruption has pervades all strata of the society from the highest levels of the political and business elites to the ordinary staff in the ministries. The multifarious manifestations of corruption in Nigeria include inflation of government contracts, fraud and falsification of accounts in the public office, examination malpractices in education institutions including universities, taking bribes and perversions of justice among the police, the judiciary and other organs administering justice and various heinous crimes against the state in the business and industrial sectors of Nigeria economy (Gana, 2006). Much has been documented on the consequences of corruption in Nigeria, in which it is out of place to re-echo them because it is not the focus of the social phenomena under investigation. However, it is my position to submit that the current spared of suicide bombing, kidnapping of Chibok and Dapchi school girls, among others are carried out by a sect known as Boko Haram and the sophisticated nature of armed robbery incidents in the country are all the 'bye-products' of corruption.

Economically, since the middle of the 1960s, crude oil has played a significant role in the economics and politics of Nigeria (Aydin, 2013; Aydin \& Lafer, 2015). The sudden and sharp rise in world crude oil prices combined with the rapid increase in crude oil export in the 1970s translated into an unprecedented inflow of foreign exchange. According to Iwayemi (2006), Ikein (2017) and Allen (2018), Nigeria has been one of the world's leading exporters of crude oil since the early 1970s. The magnitude of the wealth generation from this nonrenewable natural resource is estimated at about US $\$ 350$ billion (Sala-i-Martin \& Subramanian, 2003). In Nigeria, crude oil has been the object of a monolithic economy, with the revenue accounting for $25 \%$ of Gross Domestic Product (GDP), 90\% of foreign exchange earnings and $70 \%$ of budgetary expenditure (Inyang, 2009). Natural gas is another resource found in Nigeria in commercial quantity. Inyang (2009) argues that natural gas is second to crude oil on the list of exploited mineral resources in the Nigeria. However, the country's natural gas reserve is put at about 124 trillion standard cubic feet (Ebeku, 2018). It is on record 
that Nigeria contributes about ten percent of the world's light crude oil, which is highly valued for high yield oil products and low sulphur content.

In the area of agriculture, Nigeria is known for the production of high quality timber, palm oil, cocoa, rubber, yams, kola, fishes, citrus and other types of fruits and vegetables. These crops are mainly grown in the Southern and Eastern parts of Nigeria where the annual rainfall is above 2500 millimetres. In the savannah belt of the North, crops such as onions, tomatoes, groundnuts, cotton, millets, cattle and other ruminants are grown both for cash and food crops. Since independence in 1960, the successive governments in Nigeria had invested substantial amount of money into agricultural sector. Yet, available evidence points to continuous decline in this sector's to the GDP, to foreign exchange earnings and food requirements for the growing Nigerian population. This is as result of corrupt government officials who misappropriated funds earmarked for agriculture. The current vice president of Nigeria in person of Professor Yemi Osinbajo has blamed the immediate past president of Nigeria for the misappropriation of billions of naira allocated for agricultural ministry. In spite of corruption in agricultural sector by government officials, peasant farmers who are mainly migrant farmers contribute substantially to agricultural production in Nigeria. There is limited information (data) on the quantity of fish catch yearly in Nigeria. This is because migrant fishermen who are the major fish and other aquatic resources suppliers are uneducated, therefore, taking stock of this commodity is regarded not only as a waste of time but against their custom and belief. Kallah (2001) reports that $66 \%$ of fish and other aquatic animals consume by Nigerians are supplied by migrant fishermen. This is equally applicable to livestock production, in which pastoralist nomads supply $82 \%$ of the animal protein in Nigeria (Iro, 2006).

\section{Significance of the study}

The conceptualisation of nomadic education programme was to enhance access of the nomads to formal education in line with the country's philosophy of equality of educational opportunities for all. Since the inception of nomadic education programme, various decrees and policies were promulgated for effective and smooth implementation of the programme as explained in the findings. The landmark achievement of the Nigerian government in the area of nomadic education programme provision will be of great significance for policy makers in Kenya, India, Somalia, Mongolia, Mali and Afghanistan, among others where nomadic population are found to adopt Nigeria's method by putting in place nomads' friendly education policies for the nomads. Additionally, at the conception stage of the paper, I tried to lay hands on the literature only to be discovered that there is scarcity of literature in the field of nomadic education. Few available ones are obsolete. Therefore, this paper will serve as a research material for future researchers and scholars in nomadic education.

\section{Theoretical framework}

The main reason for conducting this study was to explore the reason for the conceptualisation of nomadic education by the federal military government of Nigeria in 1986. In light of this, the theoretical framework underpinning this study was the theory of governmentality as posited by Michel Foucault in 1978. The notion of governmentality implies that the government is acting on the conduct of people, that is, how one governs the self (Niesche, 2013). However, as Dean (1999, p.12) put it; "government concerns not only practices of government but also practices of the self (Bag, 2017). To analyse government is to analyse those practice that try to shape, sculpt, mobilise and work the choices, desires, aspirations, needs, wants and lifestyles of individuals and groups." The theory of 
governmentality, aside from focusing on the practices of government, equally looks at the relations between the forms and rationalities of power and the processes of subjectivation (the formation of governable population) and subjectification (formation of individual existence) by problematising the issue of who would govern, what governance is and who is governed and how (Foucault, 2006; Yigit \& Tatch, 2017). Foucault's governmentality is a form of governmental control aimed at guiding and shaping the conduct of her citizens (Gordon, 1991). Foucault used the word 'governmentality' to illustrate ways in which a sovereign nation uses the state apparatus to control (Martin \& Waring, 2018), and dominate her population with little or no consent for them (Simons, 2004). Based on the above assertion, the adoption of this theory is to provide the lens to understand ways in which the Nigeria's government dominates, controls, guides and shapes the nomadic population through the establishment of nomadic education programme.

\section{Limitation of the study}

In this paper, the major limitation experienced was in the area of accessing documentary materials at the National Archives of Nigeria (NAN), Abuja. I was compelled to travel on three occasions to Abuja from Lagos (about 1200 kilometres) to book an appointment with the Director General (DG) of NAN. I want to state that my first two of the trips were not successful. This is because of the DG's official engagement outside the country. This negatively delayed the completion of the paper for almost nine months.

\section{Methodological considerations}

The phenomenon under investigation has some political and historical undertone, as a result, this study is located on the realm of qualitative approach. Furthermore, since this is a social phenomenon which could not be predicted and controlled (Uzun, 2016), interpretive paradigm was adopted in order to make sense and also understand the rationale that influences the conceptualisation of nomadic education programme in Nigeria. Based on the fact that this study has both political and historical configurations, primary sources were used to generate information for the study. The reason for the use of primary sources as the major sources of evidence gathering was to ensure that the originality of the study is attended. Oral interviews and archival materials formed the key sources of information generation. For clarity purpose, five principal officials (Equere, Asaka, Inyang, Udo Ekim and Nse) (not their real names) of National Commission for Nomadic Education (NCNE) were purposively selected. It is worthy to say that each of the five participants have spent past 26 years in NCNE.

In line with the qualitative paradigm, the reason for the selection of five participants was to ensure that thick and in-depth information was gathered. I want to state that all ethical issues were adhered to before the interviews were embarked upon. Engaging the participants in oral interviews was to probe their experiences, feelings, thoughts, and understanding of nomadic education policies in Nigeria where archival materials collected were silent. I developed the oral history interviewing instrument known as Questions on Nomadic Education Policies in Nigeria (QNEPN). The instrument consists of twelve questions. Gaining access to the participants was not very difficult. This is because before the paper was conceived, I had visited the NCNE office in 2015 on behalf of my community to draw the attention of selected officials to the poor state of the only nomadic primary school. It was during the visit that I was able to develop close contact with the participants. Six days were spent to obtain in-depth information from the participants. Audio recorder and field note were used during the interview. I want to emphasise that during my interactions with all the participants, no interruption was recorded. 
In a similar vein, in order to ensure that trustworthiness of the data, archival materials such as the 1979 Nigeria's Constitution, United Nations Charter (UN), Universal Declaration of Human Rights (UDHR) of 1948, the International Covenant on Economic, Social and Cultural Rights (ICESCR) of 1966, UNESCO Convention against Discrimination in Education of 1960, National Policy on Education and Decrees were extracted from the National Archives of Nigeria (NAN). A letter was written to the Director General (gatekeeper) seeking permission to conduct research in NAN. Despite the delay, the approval was finally granted to access some documentary materials in NAN. During my visitation to NAN, I was assisted by an archivist to photocopy all the documents needed and certified as the true copies of the original. The data were transcribed and open code was used to ensure the emergence of themes. The themes were analysed using narrative analysis. According to Mura and Sharif (2017), narrative analysis is a methodological approach that goes beyond the mere analysis of texts as it is concerned with the scrutiny of the social phenomena that activate, produce, organise, and transmit stories.

\section{Research findings and discussion}

Decree 41 of December 1989 marked the turning point on the nomadic education programme in Nigeria. But before the presidential pronouncement of the establishment of nomadic education in 1986, there were so many forces that brought about the conceptualisation of nomadic education programme in the country. My interaction with the participants indicated that the 1979 Nigerian constitution, various International Conventions, National Policy on Education and Miyetti Allah Cattle Breeders Association significantly influenced the conceptualisation nomadic education programme in Nigeria. These forces are explained below.

\section{The fulfilment of the provision of the 1979 Nigerian Constitution}

It was revealed that after the Nigerian civil war of 1970, the then military government led by General Yakubu Gowon wanted the nomadic group in the country to be integrated educationally into the mainstream of Nigerian society when it was realised that the equalisation of educational opportunities for this group of people still remained elusive. This happened despite the regional government's effort already existing in this direction. Udo Ekim maintained that General Yakubu Gowon's (Head of State) effort was fruitless. This was because certain fundamental issues were not addressed such as the promulgation of a decree for the establishment of the programme. In 1975, General Yakubu Gowon's government was overthrown. Brigadier Murtala Muhammed who took over from General Gowon did not necessarily look at nomads and their education as a priority. Instead, the new military administration emphasised the eradication of corruption that enveloped the country and the return of Nigeria, after 13 years of military regime to democratic rule. The need for education for the nomads was completely ignored by the military government headed by Brigadier Murtala Muhammed. In order to ensure that democratic rule returned to Nigeria in 1979, certain democratic structures such as the Constitution Draft Committee (CDC) and the Political Bureau (PB) were set up by the military administration. The CDC's term of reference was to draft a constitution for Nigeria to ensure that democratic rule could be implemented. The 1979 Nigerian Constitution as a basic fundamental charter which outlined governmental structures, allocated powers and duties to the government, established basic decision-making procedures, placed limitations upon governmental activities, protected the right of the citizens and explained their obligations. Before the committee completed the task of drafting a new constitution, Brigadier Muhammed was killed in 1976 in a bloody coup. Nse reported that though Brigadier Muhammed was killed, the coup was not successful because the coup plotters 
were quickly overpowered by the troops loyal to the head of state. After the coup, General Obasanjo who was Brigadier Muhammed's second-in-command took over the government. General Obasanjo did not deviate from the late Muhammed's transitional programmes. Therefore in 1979, General Obasanjo successfully handed over power to a civilian government led by Alhaji Shehu Shagari after he had promulgated the 1979 Nigerian constitution into law. By implication, this marked the commencement of civil rule in Nigeria.

Asaka added that the issue before Shagari's administration was the enforcement of the 1979 Nigerian Constitution in line with democratic norms after years of abuses, deprivation and marginalisation of some segments of Nigerians including the nomads. However, before the new civilian government could begin to address nomads' issue, Shagari's administration was overthrown on $31^{\text {st }}$ December, 1983. The coup that toppled President Shagari was led by Brigadier Muhammedu Buhari. With the advent of military rule in 1983 some sections of the Nigerian Constitution, which bordered on democratic structures, were suspended. The education for nomadic people was not paramount to either the Murtala Muhammed/Obasanjo's military government. This was the case despite the fact that the nomads contributed greatly to the economy of the country through the provision of meat, fish, and hides and skins, among other products.

My interaction with Equere revealed that certain sections of the 1979 Nigerian Constitution not suspended were implemented by General Ibrahim Babangida who was then head of the new military government. In the course of implementing the 1979 Constitution, the military government realised that the nomads had not been integrated into the mainstream of the Nigerian society educationally. The realisation by the military government was made possible by various state governments where nomads were found. The exclusion of nomads from gaining access to formal education was in violation of their fundamental rights as enshrined in the 1979 Nigerian Constitution. In order to address the violation of nomads' right to education as stipulated in the Constitution, Babangida's military government conceptualised nomadic education for nomadic people. Babangida's administration, although a military regime where issues, actions and decision are taken arbitrarily, looked critically at the disadvantaged educational situation the nomads found themselves in. However, in many ways the military government used the 1979 Constitution to advance the Nigerian society. A case in point was the conceptualisation of nomadic education. Inyang declared:

Section 18 (1) of the 1979 Constitution of the Federal Republic of Nigeria says that government shall directs its policy towards ensuring that there are equal and adequate educational opportunities at all level and that government shall strive to eradicate illiteracy.

Corroborating Inyang's point, Udo Ekim observed that the Nigerian state, although under military rule, was adequately conscious of its obligations and responsibilities to all its citizens, especially in the area of the provision of education. In the view of Asaka:

I think that the basis in which nomadic education was conceived was because of Section 14 of the 1979 Constitution which states that relationship between the government and the citizens is based on the principles of democracy and social justice, and the sovereignty belongs to the people of Nigeria from whom and through whom the government derives its power and authority.

The 'principles of democracy and social justice' which Asaka cited from the 1979 Constitution connote the involvement of all manner of persons in the act of governance irrespective of place 
of birth, ethnicity, and sex, amongst others. In this context every Nigerian was to be treated equally in accordance with the provision of the Constitution. Judging from the interview with Asaka, it appears that the principles of democracy and social justice were not practiced by the government in the context of the provision of formal education to the nomads before 1986 . From the following extracts highlighted above, it would be appropriate to conclude that, the conceptualisation of nomadic education in Nigeria was based on some provisions of the 1979 Nigerian Constitution which guaranteed the nomadic people the right to formal education. It is pertinent to state that this finding was held by Mawdsley and Russo (2007) who reported that the provision of education to the migrant farmworkers and fishermen children in some states in USA was in fulfilment of the Constitution.

\section{Fulfilment of international treaties and conventions}

The various International Treaties and Conventions which the Nigerian military government signed also played a major role in the conceptualisation of the nomadic education programme. International institutions and treaties which the Nigerian government entered into agreement with, or subscribed to, were the following: United Nations Charter (UN); Universal Declaration of Human Rights (UDHR) of 1948; the International Covenant on Economic, Social and Cultural Rights (ICESCR) of 1966 and UNESCO Convention against Discrimination in Education of 1960. Before and after Nigeria attained independence in 1960, the country had explicitly accepted all human rights obligations as espoused by international human rights treaties and conventions it had entered into. Nigeria thus had an international legal obligation to respect, protect and fulfil human rights as it related to all Nigerians without discrimination on the basis of ethnicity, state of origin, sex, political opinion or other prohibited grounds. This also included the nomadic people. The fundamental human rights which Nigeria was obliged to protect included the right to life, the right to freedom of expression, the right to adequate standard of living, and access to quality education, among others. On the right of nomads for access to quality education, Udo Ekim declared that:

Look at article 26, UDHR of 1948; it says that everyone has the right to education. Education shall be free, at least in the elementary and fundamental stages. Elementary education shall be compulsory. Technical and professional education shall be made generally available and higher education shall be equally accessible to all on the basis of merit.

Udo Ekim did not only cite Article 26, UDHR of 1948 as the basis for the Nigerian government for the conceptualisation of nomadic education for nomadic people, he went a step further to say that other international treaties which various Nigerian governments signed at one time or another contributed to the reasons why nomadic education was conceptualised. He had the following to say:

Article 13 of International Covenant on Economic, Social and Cultural Rights says that the states parties to the present covenant recognize the right of everyone to education. They agree that education shall be directed to the full development of the human personality and the sense of its dignity, and shall strengthen the respect for human rights and fundamental freedoms. They further agree that education shall enable all persons to participate effectively in a free society, promote understanding, tolerance and friendship among all nations and all racial, ethnic or religious groups, and further the activities of the United Nations for the maintenance of peace. 
Udo Ekim's assertion is confirmed by the UNESCO Convention against Discrimination in Education of 1960. The document clearly spelt out in its objective that "UNESCO Convention against Discrimination in Education contributes to peace and security by promoting collaboration among nations through education, science, culture, and communication (UNESCO, 1960, p.4). This Convention places an obligation on countries that are signatories to advance equality of opportunity and treatment with regard to education. For instance, Article 1 of the UNESCO Convention of 1960 states:

For the purposes of this Convention, the term 'discrimination' includes any distinction, exclusion, limitation or preference which, being based on race, colour, sex, language, religion, political or other opinion, national or social origin, economic condition or birth, has the purpose or effect of nullifying or impairing equality of treatment in education and in particular: (a) Of depriving any person or group of persons of access to education of any type or at any level; (b) Of limiting any person or group of persons to education of an inferior standards; (c) Subject to the provisions of Article 2 of this Convention, of establishing or maintaining separate educational systems or institutions for persons or group of persons; or (d) Of inflicting on any person or group of persons conditions which are incompatible with the dignity of man (UNESCO Convention, 1960, p.5).

In a similar vein, the International Convention on the Elimination of All Forms of Racial Discrimination (ICEAFRD) of 1966 also influenced the federal government of Nigeria to reconsider the disadvantaged situation of nomads educationally. This charter, of which Nigeria is a signatory, prohibits the Nigerian government from "any form of discrimination" against its citizens. Article 5 of the ICEAFRD states that:

In compliance with the fundamental obligations laid down in article 2 of this Convention, States parties undertake to prohibit and to eliminate racial discrimination in all its forms and to guarantee the right of everyone, without distinction as to race, colour, or national or ethnic origin, to equality before the law (ICEAFRD, 1966, p.8).

In furtherance to the above, Article 5, (section E, sub-section 111, 1V \& V) clearly highlighted the obligations which each signatory state owes her citizens in term of the provision of housing, public health, medical care, social security, social services and the right to education and training. This convention went a step further with a measure in which nations that are signatories must follow in the elimination of all forms of discrimination. The measure according to Article 7 is that:

States Parties undertake to adopt immediate and effective measures, particularly in the fields of teaching, education, culture and information, with a view to combating prejudices which lead to racial discrimination and to promoting understanding, tolerance and friendship among nations and racial or ethnical groups, as well as to propagating the purposes and principles of the Charter of the United Nations, the Universal Declaration of Human Rights, the United Nations Declaration on the Elimination of All Forms of Racial Discrimination, and this Convention (ICEAFRD, 1966, p. 5).

Looking critically at the content of this convention, the interpretation was that the interest of the nomadic people as an ethnic group that were discriminated in the context of the provision of education by the federal government of Nigeria had been taken into consideration. Similarly, it would not be out of place to say that nomadic education was not conceptualised by the government as part of humanitarian service for the nomads, rather, it was in fulfilment of those international treaties and conventions. 
In a sharp contrast, countries such as India, Somalia and Kenya did not establish nomadic education on the basis of the international conventions and treaties they entered into. Instead, Dyer and Choski (1997) submitted that Indian government introduced nomadic education in the country due to the activities of nomadic leaders, who looked at acquiring knowledge through education as a means of developing oneself in particular and the community in general.

\section{National Policy on Education}

The National Policy on Education (NPE) significantly necessitated the formation of nomadic education for nomadic people in Nigeria. Before the NPE came into existence, a workshop was set up to prepare a draft National Policy on Education based on the recommendations for the 1969 National Curriculum Conference. The National Curriculum Conference of 1969 was set up to review old and identify new national goals of Nigerian education, bearing in mind the needs of youths and adults in the task of nation-building and reconstruction for social and economic well-being of the individual and the society. For the first time in Nigerian history a large number of people gathered to talk about the philosophy, structure, and content of all levels and types of education envisaged for Nigeria. The importance of the conference lay in the fact that 65 recommendations formed the basis of the NPE which the federal government of Nigeria promulgated in 1977 into law. This signalled the birth of NPE in 1977 and it was subsequently revised in 1981 and 2004. This document clearly spelt out the future of education in the Nigerian society as conceived by the federal government of Nigeria. Nine specific decision areas were identified as crucial to the attainment of the conference's objectives. One of the fundamental issues in the document was the provision of basic education for every Nigerian child irrespective of ethnicity, class, gender, state of origin. The NPE (1981, p.12) section 1, sub-section 7 (5 and 6) states that; "universal basic education in a variety offorms, depending on the needs and possibilities will be provided for all citizens, and that efforts will be made to relate education to overall community needs". In spite of this provision on the NPE, it was revealed that nomads were excluded from having access to basic education. It was on the basis of this that both the state and local governments where the nomads were found started the agitation for the inclusion of nomads in formal education in fulfilment to the provision of NPE.

\section{Miyetti Allah Cattle Breeders Association of Nigeria}

The activities of Miyetti Allah Cattle Breeders Association of Nigeria (MACBAN) positively influenced the establishment of nomadic education in Nigeria. MACBAN is a local association formed by nomads in 1979. The goal of this association was to cater for occupational needs of the nomads. The association has a simple but effective governance structure whereby elections into offices are held every four years by delegates from states where the pastoral nomads are found. Inyang reported that the nomads realised that they were over-taxed by government officials on their cattle. Furthermore, these tax officials usually spoke English while on duty which the nomads did not understand. As a result of that the nomads felt aggrieved and they wanted their children to be educated so that they would be able to confront and negotiate with the tax officials regarding the appropriate tax they had to pay. The nomads' grievances were channelled through MACBAN that later took it to the state government officials. It was the state government officials that made representation to the federal government of Nigeria for the education of nomadic people. The narrative excerpt indicated that apart from the fact that MACBAN activities thus played a paramount role in the evolution of nomadic education in Nigeria, the action of the state government officials could not be dismissed. The reason is that they acted as a mediator between the federal government 
of Nigeria and the nomads. It was believed that while the officials of the state government tabled the nomadic people's grievances to the central government, any decision reached by the central government would be communicated back to the nomads. With these intense pressure exerted on the Nigerian military government for the introduction of nomadic education, the stage was set for the official pronouncement of the birth of nomadic education programme.

\section{Evolution and development of nomadic education in Nigeria}

With the various pressures exerted for the conceptualisation of nomadic education programme in Nigeria, the actual establishment of the programme took effect in 1986.

\section{Presidential pronouncement of 1986}

Narrating what led to the presidential pronouncement on nomadic education, Udo Ekim who was the first executive secretary of the nomadic education commission and a member of the committee whose task was to design an acceptable type of education for nomads had this to say:
After the workshop's recommendations, I was called by Minister of Education, Professor J. Aminu to work out the modalities for the establishment of nomadic education. I was forced to assemble a 15 man panel to carry out the Minister's directives. After five weeks of intensive deliberation, a final report was made to the Minister.

With the receipt of the panel's report, a series of meetings were organised to 'polish' some grey areas noticed. For instance, the grey areas discussed and addressed were the organisational structure of the proposed nomadic education, and the type of instructional resources to be used in the school, among others. On completion, the Minister went on to brief the Head of State (General Ibrahim Babangida) on the need for the establishment of nomadic education. Relying on the panel's report and the workshop's recommendations, General Ibrahim Babangida pronounced the birth of nomadic education on Tuesday, $4^{\text {th }}$ November, 1986. From the analysis, the reason why General Ibrahim Babangida pronounced the establishment of nomadic education apart from the fact that it was in line with the 1979 Nigerian constitution, international conventions which the government signed, it was done in order to bring governance nearer to this mobile group.

Udo Ekim's narrative extracts pointed to the fact that the military head of state, General Ibrahim Babangida did not allow 'due process' to be followed before the pronouncement of the birth of nomadic education was made. In other words, most stakeholders were not consulted before the pronouncement was made for the establishment of nomadic education. However, looking at the process which later culminated into the presidential pronouncement of the birth of nomadic education, it is evident that nomads' position was absolutely ignored, thereby showing government highhandedness. Furthermore, the presidential pronouncement of the birth of nomadic education in Nigeria though not backed up by any decree was implemented. This goes to explain that in the Nigerian context a presidential pronouncement was a law which was being enforced as it was pronounced.

As reported above, the presidential pronouncement for the commencement of nomadic education in Nigeria was not backed by any enabling law. Instead, a Preparatory Committee (PC) was formed to implement the presidential directive on the establishment of nomadic education. According to one of the officials interviewed, the formation of the PC was done by Professor Jubril Aminu (Minister of Education). This committee was made up of 14 members and was located on Primary Education Division of the Federal Ministry of Education building in Lagos. The function of this committee was to prepare a blueprint for the nomadic education 
programme in Nigeria. Asaka explained the process that led to the eventual promulgation of Decree 28 of 1987 by the government is as follows:

The goal of setting up Preparatory Committee was to draft a blueprint for nomadic education. The draft blueprint was submitted to Federal Ministry of Justice for legal polishing. It was finally submitted to Armed Forces Ruling Council (AFRC) which then the highest law making organ in Nigeria. Thereafter, AFRC finally endorsed the submission and promulgated Decree 28 of 1987.

The above narration explained the dynamics that led to the federal government's promulgation of Decree 28 of 1987. From the finding it was discovered that the process that led to the eventual establishment of nomadic education in Nigeria was completely different from what was obtained in other countries. For instance, in Britain the establishment of formal education for the Gypsies was not done through executive fiat. Rather, it was championed by Bridget Plowden who was the Chairperson of the Central Advisory Council for Education in England. According to Foster and Norton (2012), the need for the introduction of formal education to the Gypsies was extensively debated in the parliament before it was finally approved.

\section{Decree 28 of 1987}

With the establishment of nomadic education by the government, other fundamental issues that will assist in the smooth implementation of the programme were still not put in place. As a result, in 1987, the federal military government of Nigeria promulgated Decree 28 of 1987. From the interview, it was revealed that this decree brought about the development of Nomadic Education Blueprint. Probing further on the goals of the nomadic education blueprint from Udo Ekim, instead of him responding to my question, he simply handed over to me a nomadic education blueprint and declared:

Please take a look at this document; it is nomadic education blueprint which the government came up with. The long term and short term objectives were clearly spelt out in the policy document.

Having a critical look at the document, the blueprint specifies the short term and long term objectives. In the area of short term objectives, this involves acquisition of basic functional literacy and numeracy. In my view, this implies that nomadic children who would be recipients of nomadic education would be able to read with comprehension, carry out their occupational roles such as instruction on their health and that of their animals. They would also be able to read and clearly understand local and national newspapers, simple voting instruction, write letters as well as do simple arithmetic. In the context of long term objectives, the document specified that the recipients (nomadic children) would acquire functional knowledge and skills for raising a healthy and well-adjusted family. By implication, this functional education would no doubt increase the quality of life of the nomads and fully prepare them for adequate responsibilities in a democratic state like Nigeria. In addition, recipients of nomadic education would acquire appropriate skills, abilities, and competences needed for a worthwhile living society.

In this same document (nomadic education blueprint), I went on to examine the goals of nomadic education. Nomadic Education Blueprint (1987, p. 8) specifically outlines the goals as follows:

To formulate policies and issue guidelines in all matters relating to nomadic education in Nigeria, provide fund for research and personal development for the improvement of nomadic education, development of programme on nomadic education, provision of equipment and other instructional materials, construction of classrooms and other 
facilities relating to nomadic education. To establish, manage and maintain primary schools in the settlements carved out for nomadic people, determine standard of skills to be attained in nomadic education and arrange for effective monitoring and evaluation of activities of agencies concerned with nomadic education.

Though I have painstakingly gone through the goals of nomadic education as stated in the blueprint, but that did not stop me from seeking second opinion. To accomplish this task, I enquired from Inyang the goals of nomadic education. In his response, he declared:

From the blueprint the goals of nomadic education include; providing nomadic people with relevant and fundamental basic education and improve their survival skills that will enable them to raise their productivity and income as well as empower them to participate in the socio-economic and political affairs of Nigeria.

Reflecting on the above excerpt, it is evident that the nomadic education programme when implemented should be able to develop the intellectual capacities of the nomads through the teaching of literacy, numeracy, vocational and social adjusting skills so that they can contribute more effectively to national development. Furthermore and more importantly, nomadic education when implemented should be a most potent force for the integration of the nomads into the mainstream and would eventually enable nomads to settle down in one place. With the final introduction of the nomadic education programme into the Nigerian education space through the presidential pronouncement, which was later formalised by enabling decree, I curiously asked the officials why Decree 41 of 1989 was promulgated almost two years after Decree 28 of 1987. The response from the officials and the documentary evidence are explained below.

\section{Decree 41 of 1989}

Nomadic education assumed national prominence with the promulgation in 1989 of Decree no. 41. This decree established the NCNE. However, during my visit to NAN I was fortunate to have been given this document (Decree 41 of 1989). In order to have first-hand information from this document, I referred to Part 1, which states that: The Federal Military Government hereby decrees as follows:

There is hereby established a body to be known as the National Commission for Nomadic Education [hereafter in the Decree referred to as "The Commission"] which have the functions assigned to it by this Decree. The NCNE vision statement says: "integrating the nomads into the national life by providing them with relevant and functional basic education and improving their survival skills, levels of income and productivity as well as equipping them to compete favourably in the nation's socioeconomic and political affairs (Federal Government of Nigeria Decree no. 41 of 1989, p. 2).

The decree further stated that:

The Commission shall be a body corporate with perpetual succession and a common seal and may sue or be sued in its corporate name. There is hereby established for the Commission a Governing Board [hereafter in this Decree referred as "the Board"] which shall administer and direct the affairs of the Commission. Without prejudice to the generality of subsection [1] of this section, it shall be the responsibility of the Board to exercise general control and superintendence over the policy, finances and property of the Commission, including its public relations (Federal Government of Nigeria Decree no. 41 of 1989, p.4). 
In the decree, the objectives and functions of the commission were also specified. Regarding the objectives, the decree says:

The objectives of the Commission are to: formulate policy and issue guidelines in all matters relating to nomadic education in Nigeria, provision of research and personnel development for the improvement of programs on nomadic education, development of programs on nomadic education, equipment, other instructional materials [including teaching aids and amenities], construction of classrooms and other facilities relating to nomadic education, arrange effective monitoring and evaluation of the activities of agencies concerned with nomadic education, and establish, manage and maintain primary schools for nomadic children (Federal Government of Nigeria Decree no. 41 of 1989, p. 8).

Reflecting on the objectives of the commission as stipulated by the decree, I would say that its contents are derived from the nomadic education blueprint that was produced in 1987. These objectives provided a clear organisational structure of a newly established commission and also lay a concrete foundation on ways in which nomadic education in Nigeria would be implemented. The composition of the commission as stipulated by the decree was that the commission should have 25 members. One of the members must be the Executive Secretary of the commission. He/she (the Executive Secretary) must be appointed by the President of the Federal Republic of Nigeria. Before the appointment, the person must first be selected and recommended to the President by the Minister of Education. One of the participants, Asaka, reported:

This was the step that was followed in the appointment of two previous Executive Secretaries of the NCNE in 1989 and 2007.

From the documentary evidence, other members of the commission should be drawn from the following government ministries and agencies in Nigeria: education, information and culture, internal affairs, agriculture, water and rural development, the Armed Forces of the Federation, and the Directorate of Food, Roads and Rural Infrastructures.

From the extract, it is evident that the decree clearly proscribed the composition of the membership of the commission and from where each member should be derived. Though the decree clearly stipulated who should appoint the Executive Secretary of the commission, it is silent on who should appoint other members of the commission. This led to the 'scramble' for membership by influential politicians who have little or no idea about the nomadic education programme.

Similarly, the decree also prescribed the functions of the commission. For a proper understanding of these functions, I was forced to read the decree establishing the commission repeatedly. The functions of the commission as outlined in the decree stipulate the following:

In addition to the objectives set out in section 3 of the decree the commission shall; formulate policies and issue guidelines for the implementation of Nomadic Education Programme, support research and personnel development for the advancement of the programme, fund the development of programme, fund the provision of equipment and other instructional materials, establish, manage and maintain schools in settlements carved out for nomads, including mobile and boat schools and assure quality and maintain standards through effective monitoring and evaluation (Federal Government of Nigeria Decree no. 41 of 1989, p. 10).

From the quotation, it is evident that this decree prescribed the functions of the commission to include: policy formulation and issuance of guidelines for the implementation of nomadic education programme, among others. In spite of the provision of the decree which clearly set 
out the functions of the commission, it was observed that some sections of this decree were not followed. For instance, the formulation of the policies was not done by the commission as prescribed by the decree. Rather, this function was directly performed by the different military administrations in Nigeria.

Still with the functions of the commission, to effectively and efficiently implement both the objectives and functions as stated in the decree, power was given to the commission in section 11 of Decree 41 (1989, p.3). Sub-section four stipulates that:

The commission shall, subject to any direction of the Minister, have power to do anything which in its opinion is calculated to facilitate the carrying on of its objectives and functions under this decree.

In a similar vein, the decree also gives power to the Minister of Education on the ways of issuing out directives to the commission for the implementation of its programmes. Section 11, sub-section 6 of the decree states that:

Subject to the provisions of this Decree, the Minister may give the commission directives of a general character or relating generally to matters of policy with regard to the exercise by the commission of its functions under this decree and it shall be the duty of the commission to comply with such directives" (Decree no. 41, 1989, p.5).

From the above quotes, in my view, the power of the Executive Secretary of the commission in running the affairs of the commission is drastically reduced here. This is because he (Executive Secretary) is bound by law to take directives from the Minister of Education. In my view, this process delays the smooth implementation of the nomadic education programme in Nigeria because of a serious bureaucratic bottleneck that always results in official government matters.

Be that as it may, in principle there is enormity of the works performed by the NCNE as prescribed in the decree. However, I was curious to have a fair knowledge of the organisational structure of the commission. At this juncture, I went on to probe Nse further on the ways in which the commission carries out its day-to-day functions. I was made to understand that the commission has been compartmentalised into four functional departments for easy administration, management, and control. The diagram below is the organisational chart of the National Commission for Nomadic Education.

Fig. 1: Organisational Chart of the National Commission for Nomadic Education 


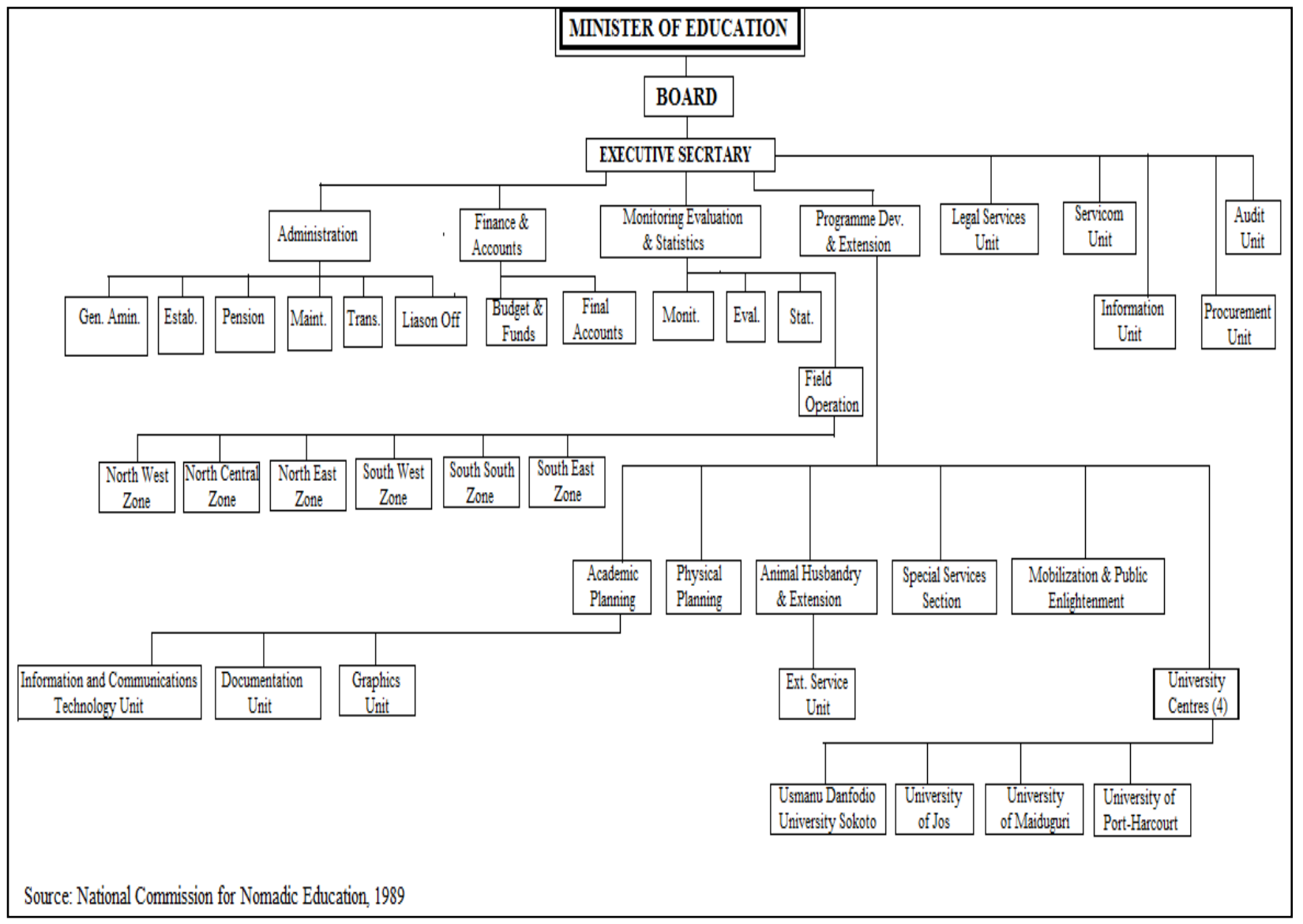

NCNE has the following principal departments: (i) Programme Development and Extension, (ii) Monitoring, Evaluation and Statistics, (iii) Administration and Supplies, and (IV) Finance and Accounts. In addition to these main departments, there are other units that perform important functions in the commission. For instance, Legal Services, Servicom, Information, Procurement and Audit Units are directly under the Executive Secretary and these units play their individual role as stated in the decree. Within these four departments, there are also 25 functional units. The Programme Development and Extension department of the commission has the responsibility to design and develop school-based and extension programmes for the education of nomads. Nse said that he has been working in this department for over 25 years. In light of this, he was in a better position to narrate the structural, organisational and functionality of the department. I therefore asked him to explain the duties of the department. He responded:

The department performs many functions. In fact, it is the engine room of the commission because it determines standards which nomadic schools should attain in the country. Design, develop and produce curricular and instructional materials. Generate data through research for programme development and modification of implementation strategies. Conduct teacher training and outreach programmes, establishment of linkages with development partners and coordination of all projects. Collate, analyse and publish information relating to nomadic education.

Within this department, there are five units, namely: academic planning, physical planning, animal husbandry, special services, lastly, mobilization and public enlightenment unit. The functions of academic planning include: conducting research for programme and improvement, conducting teacher training, designing classroom structures for different kinds of nomads based on their pattern of mobility and collating and publishing information on nomadic education. 
Furthermore, the physical planning unit of the commission has as its function the design of classroom structures for the different categories of nomads based on their pattern mobility, coordination of consultants, handling building projects, and supervision of the commission's infrastructure. In terms of the animal husbandry unit, the responsibilities of this unit include: planning, development and delivery of extension packages/outreach services to nomads, selection, training and development of nomadic extension agents, coordination of field extension work, provision of modern animal health and production activities to nomads and conducting assessment of extension activities at the field level. In the similar vein, the special services unit of the commission was set up so as to perform the following duties: to assist nomadic women to acquire basic/functional literacy, income generating skills and modern dairy processing methods, to assist the nomadic women to acquire knowledge that will help them raise their health awareness, hygiene and nutrition practices, and lastly, to enlighten the nomadic women on healthy and safe reproductive and sexual behaviour.

Notwithstanding the responsibilities of the units mentioned, Nse explained that the commission also established the mobilisation and public enlightenment unit to carry out the following functions: to sensitise and mobilise nomadic pastoralists to appreciate the value of modern education through the use of radio and other media, to sensitise the nomads to contribute meaningfully towards the education of their children through face-to-face communication and other media, particularly radio, to increase the level of support and enthusiasm of nomads with a view to improving pupils' enrolment, attendance, retention as well as adult literacy, and enlightening nomads on basic modern animal husbandry practices as well as getting acquainted with their civil rights and responsibilities. From the analysis, one could see that this department is very important in the commission. This is because apart from the physical planning of all nomadic structures in line with the nomads' migrational lifestyle which the department engaged in, the department also creates awareness among the nomads on the activities of the commission. Bearing in mind the lifestyle of the nomads, the channel in which the sensitisation is conducted is through radio, town crier and leaflets.

The Department of Monitoring, Evaluation and Statistics is another important department that was established in the commission. As the name of this department implies, Equere said that the department is made up of three units which include: Monitoring, Evaluation and Statistics. The functions of this department as explained by this official include: to assist the Executive Secretary of the commission in policy formulation and implementation in matters relating to monitoring and evaluation of the nomadic education programme; to undertake regular monitoring and evaluation of the nomadic education programme; to collate, analyse, disseminate and store data on nomadic education programme for the purpose of evaluating areas of weakness and strength in order to evolve necessary corrections; to write quarterly and annual reports on monitoring and evaluation exercise; and lastly, to arrange biannual meetings with state coordinators and quarterly meetings with zonal officers in conjunction with the office of the Executive Secretary.

From the narration, it is evident that the department is very important in the commission. My view is based on the fact that this department provides the government and other stakeholders with regular feedback and early indications of progress or lack thereof in the achievement of intended results and the attainment of goals and objectives of the nomadic education programme.

Concerning the Department of Administration and Supplies of the Commission, Asaka said:

I want to tell you that I have worked in this department for close to 26 years, therefore, my years of experience are an asset in the execution of functions of the department. 
The functions of this department include: assisting in the formulation, execution and review of policies; making recommendations on matters relating to appointments; promotions and discipline of staff; coordinating the training programmes of staff, making recommendations and carrying out activities out on staff welfare; preparing statutory and periodic reports; and supervising the activities of staff in its units. From the narration, I would say that this department is the 'engine room' of the commission. My view is based on the fact that the department is where general administrative matters are carried out. Moreover, the department also handles the training of staff for effective productivity.

My curiosity on how the commission gets funding and disburses the same was another issue that was addressed by the Executive Secretary (Inyang) of the commission. The Executive Secretary was on hand to provide all the information that related to finance. This is because in his capacity as an Executive Secretary of the commission he is one of the signatories to the commission's account. The Executive Secretary explained that the greater bulk of funds received by the commission are from the Federal Government of Nigeria. State and local governments also contribute their own share of funds to the commission as stipulated in Decree 41 of 1989. This narration suggests that the nomadic education programme is collectively funded by the three tiers of government in Nigeria.

Aside from the governments (federal, states and local governments) which significantly funded nomadic education in Nigeria, some of the participants interviewed mentioned that some international organisations such as the World Bank, and UNESCO, among others, also contributed their quota in funding the commission. This implies that the commission, apart from receiving funds from the three tiers of governments, also solicits funds from international agencies. Though the Executive Secretary had said that the federal government provides the 'lion's share' of the funds to the commission, followed by the state and local government areas, the percentage of their contribution was not stated in the decree. In my opinion, this leaves room for abuse of the process either by the state or the local government areas.

In the context of the responsibilities performed by the finance and accounts department, Inyang outlined it to include: providing professional advice to the management on financial issues, defraying of expenditure incurred by the commission in the course of its activities, such as payment of personnel emolument, fees/other remunerations or allowances, preparation, submission and defence of the commission's annual budget and sourcing of funds, preparation and submission of its annual financial statement for statutory auditing, and disbursing grants to the states, university centres and active nomadic communities.

Other functions according to this official are: preparing and submitting to the management its monthly financial information and reports; keeping of proper books of accounts and maintaining an effective internal control system; accompanying the internal auditor on yearly verification visits to zonal offices, university centres and state offices; and the submission and discussion of its audited financial statement on an annual basis to the government agencies such as office of the Auditor General of the Federation, Office of the Accountant General of the Federation and Federal Ministry of Education.

In the narrative, it appears that the department is a 'drinking pot' for all other departments in the commission. This is because other departments rely on the finance and accounts department for funds for the execution of their different functions. The achievement of any product or activity by any department in the commission is a function of the availability of funds which the department provides. However, this department could also be seen as a 'dark spot' because the embezzlement and misappropriation of the commission's funds perpetuated by officials are being covered up by the department of finance and accounts. 


\section{Conclusion}

The study investigated the dynamics surrounding the conceptualisation of nomadic education by the federal military government of Nigeria. The internal and external forces exerted on the federal military of Nigeria positively influenced the conceptualisation of nomadic education programme in 1986. With the eventual introduction of the programme, there was a 'political will' to bring the nomads into the mainstream of the Nigerian society. To accomplish this noble goal, the apparatus of government (Armed Forces Ruling Council) initiated and promulgated decrees for the implementation of the nomadic education in Nigeria.

\section{References}

Abbas, T. \& Yigit, Y. (2016). Perspectives on Ethno-National Conflict among Kurdish Families with Members in the PKK. Terrorism and Political Violence, 28(2), 297-315. Ahmed, O. (1997). Public policy in Nigeria. Ibadan: Macmillan.

Ahmed, M. (2016). Ethnicity, identity and group vitality: A study of Burushos of Srinagar. Journal of Ethnic and Cultural Studies, 3(1), 1-10.

Allen, F. (2018). Politics of State/Oil Multinational Alliance and Security Response. In P. E Ndimele (eds), The Political Ecology of Oil and Gas Activities in the Nigerian Aquatic Ecosystem (pp. 295-305). London: Elsevier Inc.

Aydin, H. (2013). Educational reform in Nigeria: the case of Multicultural Education for Peace, Love, and Tolerance. South African Journal of Education, 33(1), 1-19.

Aydin, H. \& Lafer, S. (2015). Educational Practices for a New Nigeria: An Exploratory Study. Alberta Journal of Educational Research, 61(2), 126-146.

Bag, B. (2017). Analyzing the Onset of the Iraqi Civil War 2004 from the Perspective of Inclusive and Exclusive Elite Bargains. Journal of Ethnic and Cultural Studies, 4(1), 44-64.

Bassey, M. (1999). Missionary rivalry and education expansion in Nigeria, 1885-1945. New York: The Edwin Mellen Press.

Constantine, G. R. (2017). The Biological Basis of Performativity of Identity-Linking Scientific Evidence to Social Theory. Journal of Ethnic and Cultural Studies, 4(2), 88-95.

Dean, M. (1999). Governmentality: Power and Rule in Modem Society. London, Thousand Oaks: Sage.

Dyer, C. \& Choksi, A. (1997). The demand for education among Rabaris of Kutch, West India. Nomadic peoples. 1(2), 96-105.

Ebeku, K. S. (2018). Cyprus Hydrocarbons: Lessons from the Nigerian Experience. European Scientific Journal, 14(1), 75-96.

Federal Government of Nigeria (1979). The Constitution. Lagos: Federal Government Press.

Federal Government of Nigeria (1981). National Policy on Education. Lagos: Federal Ministry of Information printers.

Federal Government of Nigeria (1987). Nomadic Education Blueprint. Lagos: Government printers.

Federal Government of Nigeria. (1987). Decree 28 of 1987. Lagos: Government printers.

Federal Government of Nigeria. (1989). Decree 41 of 1989. Lagos: Federal Ministry of Information printers.

Foucault, M. (2006). Governmentality. In J. D. Faubion (Ed.) Essential Works of Foucault, 1954-1984: Power (pp.201-22). London: Penguin.

Gana, J. (2006). Corruption and Indiscipline in Nigeria. Zaria: ABU Press. 
Gordon, C. (1991). Governmental Rationality: An Introduction. In G. Burchell, C. Gordon \& P. Miller (Eds.) The Foucault Effect: Studies in Governmentality (pp.5468). England: Harvester Wheatsheaf.

Ikein, A. A. (2017). Nigeria oil \& external exposure: the crude gains and crude pains of crude export dependence economy. The Business \& Management Review, 8(4), 396

Inyang, J. (2009). Indigenisation of the Nigerian economy. Lagos: Charity Publications.

International Convention on the Elimination of All Forms of Racial Discrimination, resolution 2106 (XX) of 21 December 1966.

Iro, I. (2006). Nomadic Education and Education for Nomadic Fulani. Retrieved on the $14^{\text {th }}$ March, 2018, from http://www.gamji.com/fulani7.htm

Iwayemi, A. (2006). Nigeria's Oil Wealth: The challenges of

Sustainable development in non- renewable natural resources dependent

economy. The Postgraduate School, University of Ibadan, 31st Interdisciplinary

research discourse.

Kallah, M.S. (2001) Rangelands in Nigeria: A partial resource appraisal towards improving livestock production. In J. O. Gefu and J. T. Amodu, Forage Production and Management in Nigeria (Eds.). (pp. 52-60). National Animal Production Research.

Khamsi, G. S., \& Stolpe, I. (2004). Decentralisation and recentralisation reforms in Mongolia: Tracing the swing of the pendulum. Comparative Education, 40(1), 29-53.

Kaya, Y. (2015). The Opinions of Primary School, Turkish Language and Social Science

Teachers regarding Education in the Mother Tongue (Kurdish). Journal of Ethnic and Cultural Studies, 2(2), 33-46.

Leggett, I. (2005). Learning to improve education policy for pastoralists in Kenya. In S.Aikman and E. Unterhalter (Eds.), Beyond Access: Transforming Policy and Practice for Gender Equality in Education (pp.128-148). Oxford: Oxfam Publishing

Madunagu, E.(2001). The making and unmaking of Nigeria: Critical essay of Nigerian History and Politics. Calabar: Clear Lines Publications.

Martin, G. P., \& Waring, J. (2018). Realising governmentality: Pastoral power, governmental discourse and the (re) constitution of subjectivities. The Sociological Review, 3(1)1224.

Mawdsley, R. D., \& Russo, C. J. (2007). A legal history of elementary and secondary student education in the USA: Balancing the rights and responsibilities of the various stakeholders. In C. C. Wolhuter, \& N. C. deWet. (Eds.). Comparative education systems and contemporary issues (pp.56-69). Pretoria: Van Schick publishers.

Momoh, T. (2010). Issues in Nigerian politics. Ibadan: Heinemann Educational Book.

Mura, P., \& Sharif, S. P. (2017). Narrative analysis in tourism: a critical review. Scandinavian Journal of Hospitality and Tourism, 17(2), 194-207.

Musa, J. M., \& Isa, J. (2018). Philosophical Assessment of Liberal Education and the Actualization of Free and Compulsory Basic Education in Nigeria. KIU Journal of Humanities, 2 (2 (B)), 141-147.

National Commission for Nomadic Education (2010). Annual Report. Kaduna: NCNE.

Niesche, R. (2013). Governmentality and my school: school principals in societies of control. Educational Philosophy and Theory. Retrieved on25th February, 2014 from http://dx.doi.org/.

Osokoya, I. O. (2010). Impact of western education on the Nigerian nomads. In I. O Osokoya (Ed.) Teaching and researching history in Nigeria (pp.41-53). Ibadan: Laurel Education Publishers Ltd.

Sala-i-Martin, X. \& Subramanian, A. (2003). Addressing the Natural Resource Curse: 
An Illustration from Nigeria. IMF Working Paper.

Simons, J. (2004). Contemporary critical theorists: From Lacan to Said. Edinburgh.

University Press Ltd.

Tahir, G. (2000). Planning and Administration of nomadic education in the context of universal basic education programme. Ibadan: Stirling-Horden Publishers.

Tahir, G. (2003). Nomadic education in Nigeria: Issues, problems and prospects. In G, Tahir (Ed.) Basic Education in Nigeria (pp.27-35). Ibadan: Stirling-Horden Publishers.

Umar, A., \& Tahir, G. (2009). Telesis of Nigerian nomadic education. In P. A. Danher, M. Kenny, \& J. R. Leder, (Eds.). Traveller, nomadic and migrant education. New York: Routletdge.

UNESCO Convention C/9 of October 25, 1960.

United Nations Charter (1945).

Uzun, K.. (2016). Critical Investigation of a Qualitative Research Article from Ontological And Epistemological Perspectives. International Journal of Social Sciences and Education Research, 2(3), 959-967.

Yigit, I. H., \& Tatch, A. (2017). Syrian Refugees and Americans: Perceptions, Attitudes and insights. American Journal of Qualitative Research, 1(1), 13-31.

Manuscript received February 02, 2018

Final revision received April 19, 2018

Accepted May 02, 2018

Louis Okon Akpan Akpan began his academic journey about 20 years ago. He bagged five degrees in different disciplines such as Geography Education, Climatology, History of Education, Comparative Education and Leadership. He is a seasoned scholar with the National Open University of Nigeria, Lagos. His research interests are aboriginal education, nomadic education, gender related issues and rural education. He has published widely in some accredited journals. E-mail: airmailo@yahoo.com 